\title{
Manajemen Pengembangan Kurikulum Sekolah Inklusi
}

\author{
Siswanto \\ Institut Agama Islam Negeri (IAIN) Curup \\ Sis66505@gmail.com \\ Eli Susanti \\ Institut Agama Islam Negeri (IAIN) Curup \\ elisusanti2304@gmail.com
}

\begin{abstract}
This study aims to explain how to develop curriculum in inclusive schools, the paradigm used in this research is the paradigm of management functions of curriculum development. Then the supporting and inbibiting factors in the process. This study uses a qualitative method using a curriculum development management approach. The data in this study were obtained through observation, in-depth interviews, and document analysis. Testing the authenticity of the data through continuous observation and triangulation of sources and methods. Data analysis uses an interactive way, including; data collection, data reduction, data presentation and conclusion drawing. The results of this study indicate that: first: the treatment given by the inclusive schools in Madrasah Aliyah Baitul Makmur towards children with different special needs is adjusted to their respective levels. For example services with regular classes with pull outs and for Madrasah Aliyah Baitul Makmur use a regular class placement / service system. Second; the development carried out at schools in Madrasah Aliyah Baitul Makmur curriculum development tailored to the characteristics / psychology of their students. The inbibiting factors are the lack of facilities and infrastructure and the absence of special teachers for children with special needs.
\end{abstract}

Keywords: Management of Curriculum Development, School of Inclusion.

Abstract : Penelitian ini bertujuan menjelaskan bagaimana cara pengembangan kurikulum pada sekolah inklusi, yakni paradigma yang digunakan dalam penelitian ini yaitu dengan paradigma fungsi-fungsi manajemen pengembangan kurikulum. Kemudian faktor-faktor pandukung dan penghambat dalam proses tersebut. Penelitian ini menggunakan metode kualitatif dengan menggunakan pendekatan manajemen pengembangan kurikulum. Data-data dalam penelitian ini diperoleh melalui observasi, wawancara mendalam, dan analisis dokumen. Pengujian keaslian data melalui pengamatan terus menerus dan trianggulasi sumber dan metode. Analisa data menggunakan cara yang interaktif, meliputi; pengumpulan data, reduksi data, penyajian data dan penarikan kesimpulan. Hasil penelitian ini menunjukkan bahwa: pertama: perlakuan yang diberikan sekolah inklusi di Madrasah Aliyah Baitul Makmur terhadap anak berkebutuhan khusus berlainan disesuaikan dengan tingkatannya masing-masing. Misalnya pelayanan dengan kelas reguler dengan pull out dan untuk Madrasah Aliyah Baitul Makmur menggunakan sistem penempatan/pelayanan kelas reguler. Kedua; pengembangan yang dilakukan pada sekolah di Madrasah Aliyah Baitul Makmur pengembangan kurikulumnya disesuaikan dengan karakteristik/psikologi siswanya. Untuk faktor penghambatnya adalah kurangnya sarana dan prasarana serta tidak adanya guru khusus anak-anak berkebutuhan khusus.

Kata kunci : Manajemen Pengembangan Kurikulum, Sekolah Inklusi.

TADBIR : Jurnal Studi Manajemen Pendidikan vol. 3, no. 2, November 2019

IAIN Curup - Bengkulu | p-ISSN 2580-3581; e-ISSN 2580-5037 


\section{Pendahuluan}

Sekolah merupakan lembaga yang didirikan oleh beberapa orang, satu sama lainnya berkoordinasi dalam melaksanakan pekerjaannya untuk mencapai tujuan bersama, Di mana, peserta didik yang ada dalam sekolah itu sendiri sangat beranekaragam, kepribadian dan karakternya, baik secara intlejensi, fisik dan psikisnya. Kesemuanya itu, dalam dunia pendidikan lebih akrab disebut dengan anak-anak luar biasa atau anak-anak berkebutuhan khusus (ABK). Karena Sesuai dengan apa yang ada pada Undang-Undang Dasar 1945 pasal 31 ayat 1 dan Undang-Undang Sistem Pendidikan Nasional dan juga pada bab IV pasal 5 ayat 1 dinyatakan yaitu: "setiap warga negara mempunyai kesempatan yang sama dalam memperoleh pendidikan yang bermutu, dalam hal ini termasuk di dalamnya adalah anak yang berkebutuhan khusus (ABK)".

Sering kita dengar sebuah istilah "luar bisa" merupak sebutan lain dari bagi mereka yang tidak normal yakni yang memiliki fisik kurangan sempurna, misalnya buta, tuli, keterlambatan mental dan lain-lain. Dimana itu semua tidak dialami oleh orang normal pada umumnya. Kelainan itu, dapat dilihat dari segi fisik, psikis, sosial dan moral peserta didik (Haris, 2006). Sebenarnya, anak-anak yang di sebutkan di atas, dalam lingkungan sekolah dapat disatukan dengan anak-anak yang normal. Sekolah untuk mempersatukan anak-anak di atas, pada saat sekarang ini lebih populer ataupun lebih akrab disebut dengan sekolah inklusi.

Sementara itu, istilah kata "sekolah inklusi" adalah wadah atau tempat pendidikan yang baru yang dipergunakan untuk mendeskripsikan penyatuan bagi anak-anak berkebutuhan khusus (ABK). Akan tetapi, terkadang dalam masyarakat penafsiran tentang anak-anak ABK masih sering salah ditafsirkan. Anan -anak yang berkemampuan unggul dan berprestasi luar biasa tidak termasuk anak yang berkebutuhan khusus (Smith, 2009). Untuk meluruskan dan memberikan hak yang sama tentang asumsi di atas, maka pemerintah saat sekarang ini, telah memberikan keleluasaan bagi sekolah-sekolah umum untuk menerima anak-anak ABK. Sekolah inklusi merupakan sebuah model sekolah dimana, selalu mengkombinasi keberbedaan, keunikan serta keberagaman masing-masing siswa tanpa dibeda-bedakan anak yang berasal dari latar belakang etnik/suku, kondisi sosial, kemampuan ekonomi, afiliasi/kerjasama politik, bahasa, geografis (keterpencilan) tempat tinggal, jenis kelamin, agama/kepercayaan dan perbedaan kondisi fisik atau mental.

Dengan sistem sekolah inklusi ini, anak-anak yang berkebutuhan khusus dapat bersama belajar bersama dengan anak-anak pada umumnya, sehingga mereka dapat menyesuaikan diri dengan kehidupan nyata sehari-hari. Karena selama ini, adanya asumsi yang berkembang dalam masyarakat bahwa lulusan/tamatan SLB kurang diterima dengan oleh masyarakat, yakni disebabkan yaitu kurangnya sosialisasi tersebut (Undang-Undang Nomor 20 Tahun 2003). 
Oleh sebab itu, dengan adanya sekolah inklusi ini akan dapat memberikan kesempatan seluas-luasnya bagi anak berkebutuhan khusus untuk belajar di sekolah umum yang dekat dengan tempat tinggalnya, hal ini diharapkan dengan upaya tersebut dapat menuntaskan program pemerintah wajib belajar sembilan tahun, yang di dalamnya termasuk anak berkebutuhan khusus. Dengan harapan semua itu akan dapat terlaksana dengan baik.

Sementara itu, perlu kita pahami bahwa lembaga sekolah didirikan untuk mencetak alumni/manusia yang bermutu dan sesuai dengan tujuan yang diharapkan. Oleh karena itu, kurikulum menjadi sentralnya untuk menuju mutu anak itu sendiri. Perkembangan anak didik hanya akan tercapai apabila dia memperolah pengalaman belajar melalui semua kegiatan yang disajikan sekolah. Kurikulum merupakan penjabaran dari mata pelajaran yang dapat memberikan pngalaman pada peserta didik, dan dirancang untuk mereka sendiri..

Sedangkan berkaitan kurikulum sekolah inklusi, penyelenggaraannya pada saat sekarang masih berpedoman pada kurikulum yang berlaku pada umumnya. Kurikulum merupakan suatu hal yang sangat penting. Kerna kurikulum disusun bertujuan untuk dapat mewujudkan tujuan sebuah pendidikan. Melalui hal tersebut maka SDM dapat diarahkan demi kemajuan suatu bangsa akan ditentukan. Pengembangan kurikulum harus dapat disesuaikan dengan tahap perkembangan peserta didik, dalam rangka bangunan Nasional dan perkembangan peradaban ilmu pengetahuan dan teknologi.

Seharusnya, muatan mata pelajaran yang diajarkan hendaknya disesuaikan dengan kebutuhan dari karakteristik masing-masing peserta didik. Karena adanya kesulitan dalam penentuan metode, strategi, fasilitas dan media pembelajaran. Hal lain yang yang bertanggung jawab terkait dengan pembelajaran adalah pihak guru (Haris, 2006). Karena semuanya harus bermuara kepada pencapaian terget kurikulum yang berlaku. Sebenarnya program yang dibuat harus bersifat dinamis yang dilanjutkan dengan sintetik terhadap berbagai perubahan dan kemajuan peserta didik. Yang mana, diantara tim penyusun kurikulum selalu menjadikan sebuah profesi dan keahlian bagi anak yang berkebutuhan khusus (ABK), untuk dapat menjadi contoh pada sekolah inklusi.

Namun, berdasarkan realita yang ada di lapangan, setiap satuan pendidikan dalam penyelenggaraan pembelajarannya, harus berpegang pada kurikulum terbaru yang berlaku, yaitu kurikulum KTSP tahun 2010. Oleh karena itu, dalam penyelenggaraan sekolah khusus untuk anak-anak yang berkebutuhan khusus (ABK), khusus dewasa ini juga harus mengacu kepada kurikulum yang tingkat satuan pembelajaran pada umumnya yaitu "kurikulum KTSP".

Untuk mempermudah dalam proses pembelajaran, kurikulum yang di gunakan di sekolah inklusi tetap berpedoman pada kurikulum reguler (KTSP), selanjutnya ditambahkan dengan kurikulum modifikasi dan kurikulum yang di individualisasikan sesuai dengan kemampuan dan karakteristik peserta didik. 
Modifikasi itu dapat dilakukan dengan cara memodifikasi alokasi waktu atau isi/materi.

Dalam penyelenggaraan sekolah inklusi yang berdasarkan kepada kurikulum tingkat satuan pembelajaran tersebut, seharusnya disesuaikan dengan kebutuhan dan karakteristik masing-masing jenis peserta didik cacat fisik atau mental. Menyikapi hal tersebut, terdapat beberapa persoalan guna mendukung terhadap pengetahuan dalam menejemen pengembengan kurikulum sekolah inklusi dalam proses belajar mengajar.

\section{Kajian Teori}

\section{1) Manajemen}

Manajemen berasal dari kata kerja to manage yang berarti control. Sedangkan dalam bahasa Indonesia dapat diartikan mengendalikan, menangani atau mengelola (Hikmat, 2009). Sedangkan manajemen dalam bahasa Inggris artinya to manage yang berarti mengatur atau mengelola. Dalam arti khusus bermakna memimpin dan kepemimpinan, Gerge R. Terry menyatakan, manajemen merupakan suatu proses yang terdiri dari PUAC (planning, organizing, actuating dan controlling) yang memiliki tujuan yang sama. Atau berbagi jenis kegiatan yang berbeda itulah yang membentuk manajemen sebagai suatu proses yang tidak dapat dipisah-pisahkan dan sangat erat hubungannya (John M. Echols dan Hassan Shadily, 2000).

Sebenarnya banyak para ahli mengatakan manajemen, sebagaimana dikemukakan oleh beberapa penulis buku manajemen, di antaranya Malayu, S.P. Hasibun, Mary Parker Follet, Horold Koontz, Cyril O’Donnel, James A.F. Stoner dan lain-lain, semua pada intinya saling berkaitan satu sama lainnya dan hampir sama. Sehingga manajemen pada intinya sebuah proses yang selalu berkaitan dengan perencanaan, pengorganisasian, kepemimpinan, pengendalian dalam sebuah organisasi untuk mencapai tujuan bersama.

Setelah pengertian manajemen diketahui, pembahasan berikutnya adalah manajemen pendidikan. Manajemen pendidikan adalah sebuah usaha mengarahkan orang-orang (warga sekolah) agar melaksanakan aktivitas kependidikan untuk mencapai tujuan pendidikan yang telah dirancang bersama. Sedangkan menurut Suharsimi Arikunto: "manajemen pendidikan merupakan rangkaian segala kegiatan yang menunjuk kepada usaha kerjasama dua orang atau lebih untuk mencapai tujuan pendidikan yang telah ditetapkan" (Arikunto, dkk, 2008).

Seperti penjelasan di atas, maka manajemen pendidikan dapat diartikan sebagai suatu proses pengelolaan lembaga pendidikan dengan cara menyiasati sumber-sumber belajar dan hal-hal yang terkait untuk mencapai tujuan pendidikan secara efektif dan efisien. Sedangkan istilah manajemen sekolah seringkali disandingkan dengan istilah administrasi sekolah (Fahrurroz, 2008). 


\section{2) Kurikulum}

Secara bahasa, kurikulum berasal dari bahasa Yunani, curir yang berarti 'pelari' dan curere yang berarti tempat berpacu. Jadi Curriculum diartikan "jarak yang harus ditempuh oleh pelari” (Sudjana, 2008). Sedangkan pendapat lain mengatakan bahwa istilah kurikulum digunakan pertama kali pada dunia olahraga pada zaman Yunani kuno yang berasal dari kata curir dan curere. Pada waktu itu kurikulum diartikan sebagai jarak yang harus ditempuh oleh seorang pelari. Istilah lainnya adalah tempat berpacu/tempat dari mulai start sampai finish (Sanjaya, 2008).

Sehingga Hasan Langgulung kemudian juga menyimpulkan sebagaimana dikutip oleh Sulistyorini, bahwa Istilah kurikulum berasal dari dunia olah raga pada zaman Romawi kuno di Yunani, yang mengandung pengertian suatu jarak yang harus ditempuh dalam kegiatan berlari mulai dari garis start sampai finish (Sulistyorini, 2009).

Selanjutnya istilah kurikulum digunakan dalam dunia pendidikan. Para ahli pandidikan misalnya Murray Print, Robert M. Hutchins, Romine, Horalt Alberty dan lain-lain, mereka menafsirinya berbeda-beda tantang kurikulum. Namun demikian, semuanya itu ada kesamaannya, yaitu kurikulum berhubungan erat dengan usaha mengembangkan peserta didik sesuai dengan tujuan yang ingin dicapai (Sanjaya, 2008). Dengan kata lain bahwa kurikulum merupakan alat untuk mencapai tujuan pendidikan.

Berdasarkan pengertian di yang terkandung di atas, kurikulum sekolah merupakan instrumen strategis dalam upaya pengembangan kualitas SDM baik jangka pendek maupun jangka panjang. Selain itu, kurikulum sekolah juga memiliki koherensi yang amat dekat dalam upaya pencapaian tujuan sekolah atau tujuan pendidikan. Sehingga kurikulum juga dapat diartikan sejumlah mata pelajaran yang harus ditempuh atau diselesaikan anak didik untuk memperoleh ijazah.

Oleh karena itu, kurikulum sebagai suatu program atau rencana untuk mendapatkan pengalaman belajar, kegiatan nyata/praktek yang nyata dalam pendidikan. Sedangkan dalam UU SISDIKNAS NO. 20 Tahun 2003, mendefinisikan bahwa:

"Kurikulum sebagai seperangkat rencana dan pengaturan mengenai tujuan, isi, dan bahan pelajaran serta cara yang digunakan sebagai pedoman penyelenggaraan kegiatan pembelajaran untuk mencapai tujuan pendidikan tertentu" (Undang-undang Sistem Pendidikan Nasional. 2003).

Pengertian tersebut di atas, yang secara dipergunakan dalam pendidikan Indonesia. Sehingga dapat disimpulkan bahwa kurikulum dalam dunia pendidikan merupakan seperangkat mata pelajaran yang mengatur mengenai bagaimana pembelajaran yang dilakukan itu dapat mencapai tujuan pendidikan 
baik jangka pendek atau jangka panjang. Oleh karena itu, aktivitas yang berada disekolah harus mendidik, mencerdaskan, membangkitkan aktivitas dan kreativitas anak, efektif, demokratis, menyenangkan dan mengasyikan. Dengan sprit tersebut di atas, maka kurikulum akan menjadi pedoman dalam bagi penyelenggaraan pendidikan dan pengajaran di sekolah.

\section{3) Komponen-Komponen Kurikulum}

Tujuan, isi, evaluasi dan metode merupakan komponen dari kurikulum, yang saling terkait satu sama lain. kurikulum sebagai guiding instruction juga merupakan antisipatori dan bukan hanya sebagai reportial. Oleh karena itu, kurikulum merupakan suatu hal yang sangat menetukan atau paling tidak sebagai antisipasi/pencegahan terhadap sesuatu yang akan terjadi.

Sistem kurikulum merupakan satu kesatuan komponen yang satu sama lain saling berkaitan. Serta saling keterkaitan antara komponen yang satu dengan komponen lainnya, maka sistem kurikulum akan terganggu pula. Komponenkomponen kurikulum dapat dilihat dalam gambar di bawah ini:

\section{Gambar 1}

\section{Bagan Komponen-Komponen Kurikulum}

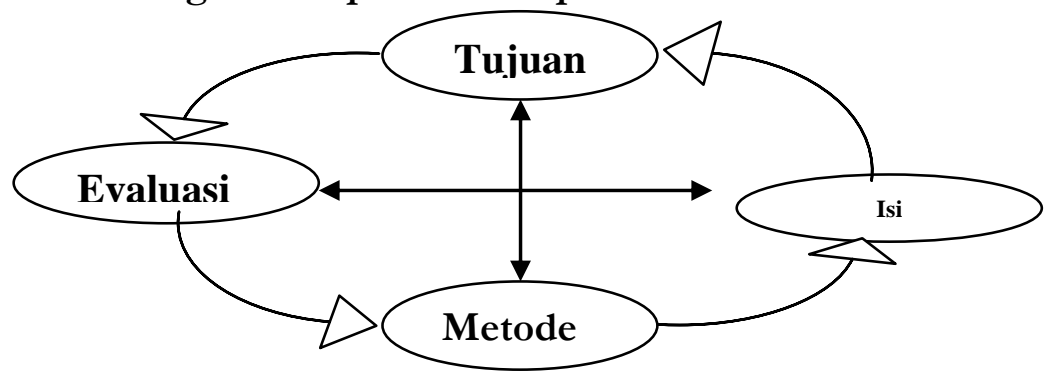

Bagan di atas memberikan gambaran bahwa sistem kurikulum terbentuk oleh empat komponen, yaitu komponen tujuan, isi kurikulum, metode atau strategi pencapaian tujuan, dan komponen evaluasi. Sebagaimana kata kunci untuk memudahkannya, maka disingkat dengan kata "TIME" yaitu tujuan, isi, metode dan evaluasi (Sanjaya, 2008). Selanjutnya keempat bagian kurikulum tersebut saling berkaitan, setiap komponen bertalian erat dengan ketiga komponen lainnya. Misalnya apabila salah satu komponen berubah maka semuanya akan ikut berubah, sebagai contoh jika tujuan yang baru, atau proses belajar mengajar, metode atau cara penilaian, maka komponen yang lain ikut berubah. Jika tujuannya jelas, maka bahan pelajaran maupun evaluasinya akan lebih jelas (Nasution, 1995). Berikut ini akan dijelaskan masing-masing komponen.

\section{4) Pengembangan Kurikulum}

Pengembangan kurikulum mempunyai makna yang cukup luas, menurut Sukmadinata pengembangan kurikulum bisa berarti menyusun kurikulum yang 
sama sekali baru (curriculum construktion), atau dikatakan penyempurnaan kurikulum yang sudah ada (curriculum improvement). Ataupun pengembangan kurikulum merupakan menyusun seluruh seperangkat kurikulum mulai dari dasar-dasar kurikulum, struktur dan sebuah mata pelajaran, garis besar program pengajaran sampai dengan pedoman-pedoman pelaksanaan (macro curriculum).

Jadi dari beberapa pengertian di atas, maka dapat diambil kesimpulan bahwa pengembangan kurikulum pada hakekatnya merupakan proses penyusunan rencana tentang isi dan bahan pelajaran yang harus dipelajari serta bagaimana cara mempelajari kemudian dievaluasi secara terus menerus.

\section{5) Model-Model Pengembangan Kurikulum}

Untuk memilih suatu model pengembangan kurikulum bukan saja didasarkan pada kelebihan dan kemungkinan pencapaian hasil yang optimal. Tetapi juga disesuaikan dengan sistem pendidikan dan sistem pengelolaan pendidikan yang dianut. Model pengembangan kurikulum dalam sistem dan pengelolaan pendidikan yang sentralistik tentunya akan berbeda dengan sistem dan pengelolaan pendidikan yang desentralistik.

Model pengembangan dalam kurikulum yang sifatnya subjek akademis berbeda dengan kurikulum humanistik, teknologis dan rekonstruksi sosial. Model merupakan abstrak dunia nyata atau representasi peristiwa kompleks atau sistem dalam bentuk naratif, matematis, grafis, serta lambang-lambang lainnya. Lebih lanjut ditegaskan model bukanlah realitas, akan tetapi merupakan representasi realitas yang dikembangkan dari keadaan. Dengan demikian, model pada dasarnya berkaitan dengan rancangan yang dapat menerjemahkan sesuatu ke dalam realitas, yang sifatnya lebih praktis.

Model berfungsi sebagai sarana untuk mempermudah berkomunikasi, atau sebagai petunjuk yang bersifat perspektif untuk mengambil keputusan atau sebagai petunjuk perencanaan untuk kegiatan pengelolaan. Model pengembangan kurikulum yang abstrak berikut ini adalah model yang biasanya digunakan dalam banyak proses pengembangan kurikulum. Dalam model ini, kurikulum lebih banyak mengambil posisi pertama yaitu sebagai rencana dan kegiatan. Ide yang dikembangkan pada awal lebih banyak berfokus pada kualitas apakah yang harus dimiliki dalam belajar suatu disiplin ilmu, teknologi, agama, seni dan sebagainya.

Pada fase pengembangan ide, permasalahan pendidikan hanya terbatas pada masalah transfer dan transmisi. Masalah yang muncul di masyarakat atau ide tantangan masyarakat masa depan tidak menjadi kepedulian kurikulum. kegiatan evaluasi diarahkan untuk menemukan kelemahan kurikulum yang ada, model yang tersedia dan dianggap sesuai untuk suatu kurikulum baru dan diakhiri dengan melihat hasil kurikulum berdasarkan tujuan yang terbatas (Indrayanto, 2009). 
Secara konseptual, model kurikulum dapat dibedakan menjadi empat macam, yaitu pertama; model kurikulum subyek akademik (KSA), sebagai pendidikan klasik yang dipengaruhi oleh filsafat pendidikan perenialisme dan esensialisme. Kedua; model kurikulum humanistik (rasa kemanusiaan atau berhubungan dengan kemanusiaan atau rasa kemanusiaan) yang banyak dipengaruhi oleh filsafat pendidikan progresivisme dan romantisisme, ketiga; model intraksionalisme dan keempat; model kurikulum teknologis atau berbasis kompetensi (Sukmadinata, 2006).

Kurikulum dan hasil belajar berfokus pada aktifitas peserta didik dan hasil belajar yang dapat dicapai. Kemudian di dalamnya memuat seperangkat hasil balajar untuk peserta didik yang manjelaskan tentang hasil belajar yang daharapkan dapat dicapai oleh peserta didik di sekolah. Untuk memperkaya pengalaman dalam membangun kurikulum, berikut ini diuraikan beberapa pendekatan-pendekatan dan model-model pengembangan kurikulum (Sagala, 2009).

Dalam pengembangan kurikulum ada beberapa model yang dapat digunakan, setiap model memiliki kekhasan tertentu baik dilihat dari keluasaan pengembangan kurikulumnya itu sendiri maupun dilihat dari tahapan pengembangannya sesuai dengan pendekatannya:

Model pengembangan kurikulum oleh Taba lebih menitik beratkan bagaimana cara pengembangan kurikulum sebagai suatu proses memperbaiki dan menyempurnakan dengan cara induktif. Ada lima langkah pengembangan kurikulum model Taba sebagaimana tersaji dalam gambar berikut ini :

\section{Gambar 2}

Model Pengembangan Kurikulum Taba

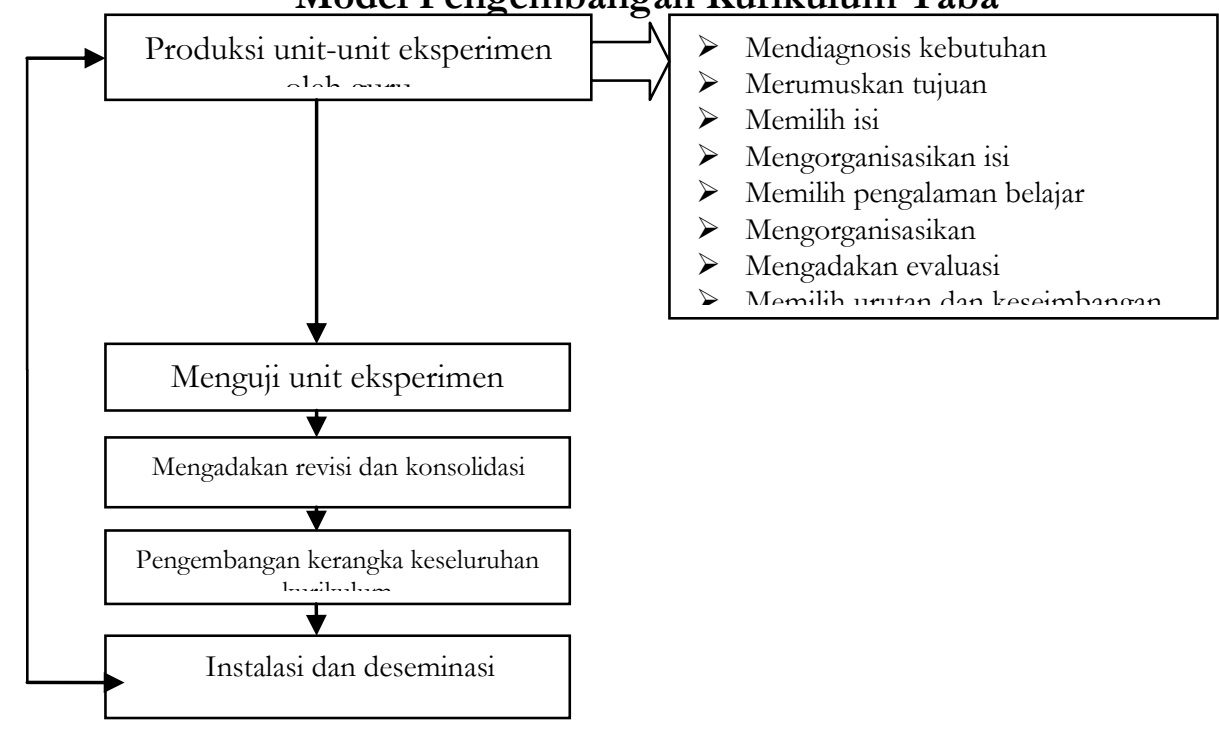


Model pengembangan kurikulum menurut Tyler lebih bersifat bagaimana merancang suatu kurikulum, sesuai tujuan dan misi suatu lembaga pendidikan. Dalam ringkasannya model ini mencerminkan dua pengaruh luas, yaitu pertama; pengaruh Dewey yang dapat dilihat dalam tiga sumber besar Tyler obyektivitas pendidikan. Kedua; orientasi sikap dari para pendidik seperti Bobbit dan Thorndike yang mempengaruhi konsepnya, bahwa tujuan dari pendidikan yaitu untuk membawa perubahan dalam sikap siswa. Penekanan Tyler dalam merancang kurikulum harus sesuai dengan tujuan dan misi suatu instansi pendidikan. Hal fundamental dalam pengembangan kurikulum adalah:

a) Berhubungan dengan tujuan pendidikan yang ingin dicapai

b) Berhubungan dengan pengalaman belajar untuk mencapai tujuan

c) Pengorganisasian pengalaman belajar

d) Berhubungan dengan evaluasi.

Dengan pemahaman tersebut, akan memudahkan bagi guru dalam mendesain lingkungan yang dapat mengaktifkan siswa memperoleh pengalaman belajar. Model pengembangan kurikulum Tyler dapat dilihat pada gambar di bawah ini.

\section{Gambar 3}

Model Pengembangan Kurikulum Tyler

Objectives

Selecting learning experiences

Organizing learning experiences

\section{Evaluation}

Ada beberapa prinsip dalam menentukan pengalaman belajar siswa. Pertama; pengalaman siswa harus sesuai dengan tujuan yang ingin dicapai, kedua; setiap pengalaman belajar harus memuaskan siswa, ketiga; setiap rancangan pengalaman siswa belajar sebaiknya melibatkan siswa, keempat, mungkin dalam satu pengalaman belajar dapat mencapai tujuan yang berbeda.

Menurut Weinstein dan Fantini bahwa, suatu model dikembangkan melalui perwakilan dari perpindahan kedudukan; model ini memusatkan pada kebutuhan dan perhatian dari orang yang belajar. Mereka berdua telah mengembangkan satu model pada apa yang mereka sebut pendidikan identitas.

Model implementasi kurikulum yang dikembangkan dan digunakan menurut Miller dan Seller, untuk mendukung proses belajar mengajar. Oleh karena itu, guru yang profesional akan mampu mengembangkan kurikulum 
dengan merancang sejumlah inovasi dan berbagai perubahan untuk mencapai tujuan belajar yang optimal.

Manusia itu berada pada proses perubahan (becoming, developing, changing), dan sesungguhnya mempunyai kekuatan untuk berkembang sendiri, tetapi berhubung ada hambatan-hambatan, maka ia membutuhkan orang lain unuk membantu memperlancar atau mempercepat perubahan itu hal itu adalah penjelasan dari Carl Ragers. Salah satu cara untuk proses itu adalah melalui proses pendidikan. Hal ini juga dikatakan bahwa kurikulum diperlukan dalam rangka mengembangkan individu yang berbeda, luwe dan adaptif terhadap situasi perubahan. Kurikulum tersebut hanya dapat disusun dan diterapkan oleh unsur-unsur pendidikan serta yang lainnya yang terbuka, luwes dan berorientasi pada proses.

\section{Gambar 4}

Model Pengembangan Kurikulum Carl Rogers

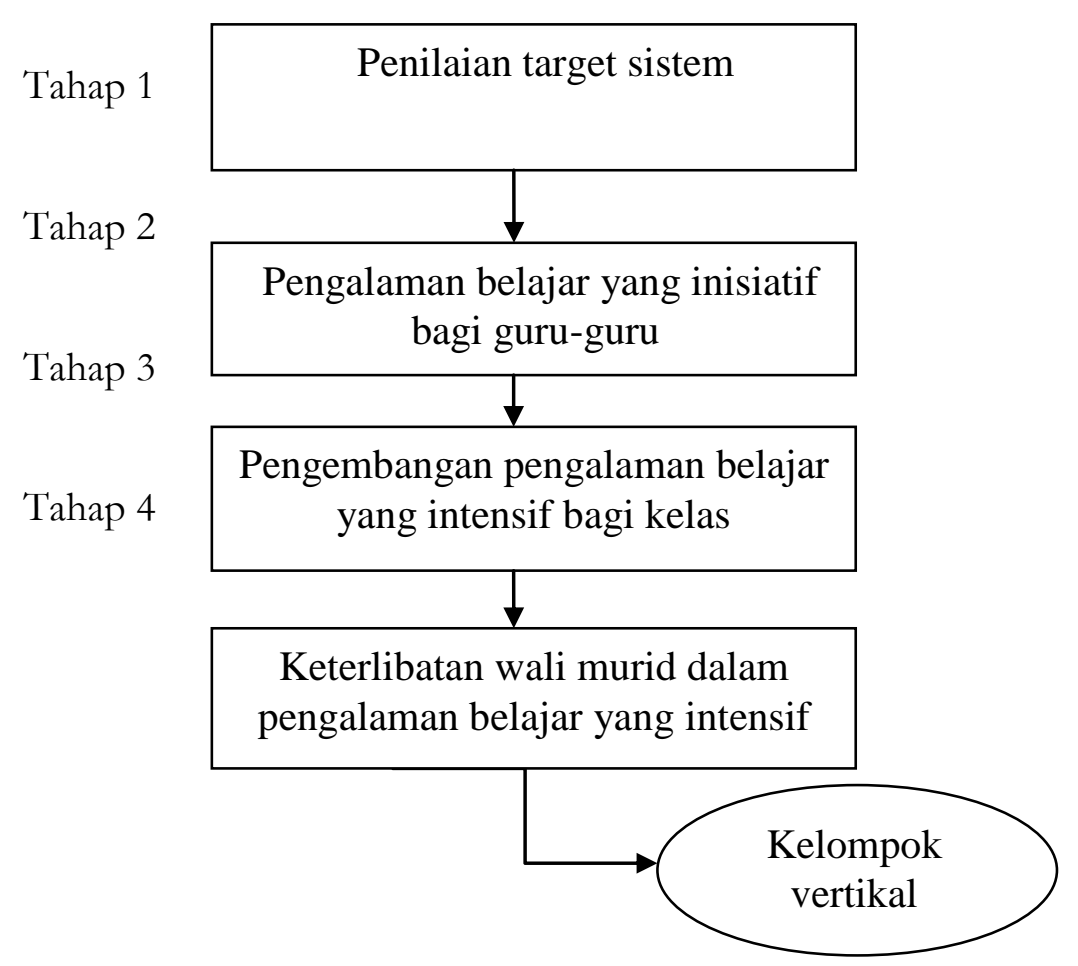

Menurutnya model kurikulum harus bersifat simpel, komperhensif dan sistematis. Model yang dikembangkannya dapat digunanakan beberapa bagian. Satu; untuk menyempurnakan kurikulum sekolah dalam bidang-bidang khusus, misalnya pada bidang studi tertentu di sekolah baik dalam tataran perencanaan kurikulum maupun dalam proses pembelajaran, dua; Model ini juga dapat digunakan untu membuat keputusan dalam merancang suatu program 
kurikulum, tiga; model ini dapat digunakan dalam mengembangkan program pembelajaran secara khusus.

\section{Metode Penelitian}

Kajian ini menggunakan metode penelitian kualitatif, dengan menggunakan pendekatan pengembangan kurikulum. Adapun pengumpulan data dengan menggunakan wawancara, dokumentasi dan observasi. Untuk sampel yang akan diwawancarai adalah kepala sekolah guru-guru yang ada di MA Baitul Makmur serta 4 Siswa Madrasah. Wawancara digunakan untuk mengetahui bagaimana cara kepala Madrasah dan dewanguru mengembangkan kurikulum untuk anak-anak yang statusnya berkebutuhan khusus yang ada di Madrasah tersebut. Adapun kajian analisis data kami menggunakan dengan cara reduksi data, penyajian data dan langsung penarikan kesimpulan.

\section{Pengembangan Kurikulum Sekolah Inklusi MA Baitul Makmur}

Menurut pendapat Ibu Nurani, M.Pd selaku kepala Madrsah mengatakan bahwa cara pengembangan kurikulum pada sekolah ini adalah dengan cara melihat karakter peserta didik yang ada. Kemudian guru dalam mengajar menyesuaikan kurikulum yang ada (Amin, M., Arsil, Fathurrochman, I., Bahri, S., Rahmaningsih S., 2019). Kemudian hal ini senada dengan yang dikatakan waka kurikulum yang kemudian menambahkan bahwa kurikulum K13 itu dikembangkan sesuai dengan kebutuhan dan karakter peserta didik yang ada di Madrasah ini. Terutama anak-anak yang berkebutuhan khusus. Anak yang berkebutuhan khusus dapat belajar dengan sebagaimana mestinya.

Menurut Novitasari yang termasuk anak yang berkebutuhan khusus mengatakan belajar di MA Baitul Makmur sangatlah menyenangkan karena guru-gurunya bisa dengan mudah menyampaikan materi pelajaran yang sehingga saya dapat memahaminya dengan mudah. Misalnya ketika belajar bahasa arab guru lebih menekankan penghafalan mufrodat pada pembahasan tersebut dan diulang-ulang. Terkadang materi yang disampaikan disesuaikan dengan kemampuan siswa yang ada.

Menurut Siswanto (2011) Pada dasarnya dalam pembelajaran pada Madrasah MA baitul makmur menggunakan pengembangan kurikulum model Taba yang konsepnya yaitu:

a) Mendiagnosis kebutuhan dengan cara menentukan kebutuhan siswa, melalui diagnosis tantang berbagai kekurangan dan latar belakang peserta didik

b) Merumuskan tujuan khusus

c) Memilih isi sesuai tujuan dengan mempertimbangkan validitas dan kebermaknaan bagi peserta didik

d) Mengorganisasi isi dengan menyusun urutannya sehingga jelas untuk peserta didik yang mana kurikulum itu diberikan

e) Memilih pengalaman belajar yang harus dimiliki peserta didik 
f)Mengorganisasi pengalaman belajar ke dalam paket-paket kegiatan

g) Mengevaluasi dengan mempersiapkan dengan berbagai teknik dan prosedurr yang dipersyaratkan

h) Melihat kesesuaian antara isi, pengalaman belajar dan tipe-tipe belajar siswa.

Dengan mengembangkan model pengembangan kurikulum di atas menjadikan siswa yang berkebutuhan khusus di Madrasah tersebut dapat mengukuti pembelajaran sebagai mana siswa yang normal. Hal yang paling mendukung pada Madrasah ini adalah para dewan guru yang memiliki kesabaran dan kesungguhan dalam melaksanakan proses pembelajaran. Adapun yang menjadi hambatan/ kendala pengembangan ini adalah kurangnya perhatian pemerintah daerah tentang masalah pendidikan inklusif dan sarana-prasaran yang kurang memadahi.

\section{Kesimpulan}

Pengambangan kurikulum sekolah inklusi yang ada di MA Baitul Makmur yaitu dengan menyesuaikan dengan kondisi/karakter peserta didik yang ada. disesuaikan dengan tingkatannya masing-masing. Misalnya pelayanan dengan kelas reguler dengan pull out dan untuk Madrasah Aliyah Baitul Makmur menggunakan sistem penempatan/pelayanan kelas reguler. Model pengembangan kurikulum yang dilakukan adalah mengikuti konsep model Taba. Proses pengembangan kurikulum sekolah inklusi di MA Baitul Makmur disesuaikan dengan karakteristik/psikologi peserta didik berkebutuhan khusus yang mereka alami. Kurangnya sarana dan prasaran yang memadahi sehingga perlu adanya dukungan dari pemerintah daerah untuk kemajuan Sekolah inklusi di MA Baitul Makmur.

\section{Daftar Pustaka}

Amin, M., Arsil, Fathurrochman, I., Bahri, S., Rahmaningsih S. (2019). Manajemen Mutu Pendidikan Pada Perguruan Tinggi. Curup; LP2 IAIN Curup.

Arikunto, Suharsimi, Lia Yuliana, Manajemen Pendidikan, Yogyakarta: Aditya Media, 2008.

Denis dan Ny. Enrice, Inklusi; Sekolah Ramah Untuk Semua, Bandung: Nuansa, 2009.

Depertemen Pendidikan Nasional; Kurikulum 2004 Sekolab Menengah Atas (SMA)

Pedoman Khusus Pengembangan Silabus Kompetensi Siswa Sekolah Menengah Atas, Jakarta: Binatama Raya, 2005.

Depertemen Pendidikan Nasional, Badan Standar Nasional Pendidikan (BSNP), Petunjuk Teknis Pengembnagan Silabus dan Contoh/Model Silabus Mata Pelajaran Geografi SMA/MA, Jakarta: BSNP, 2006.

Diknas Pendidikan Kota Yogyakarta, Petunjuk Teknis Penyelenggaraan Pendidikan Inklusi Di Kota Yogyakarta, Yogyakarta: Diknas, 2009. 
Direktorat Pembinaan Sekolah Luar Biasa, Pedoman Manajemen Dan Pembelajaran Sekolah Inklusi Tunagrabita Ringan (c), Jakarta: Direktorat Jendral Manajemen Pendidikan Dasar Dan Menengah, 2010.

Direktorat Pembinaan Sekolah Luar Biasa, Pedoman Manajemen Dan Pembelajaran Sekolah Inklusi Tunarungu (B),Jakarta: Direktorat Jendral Manajemen Pendidikan Dasar Dan Menengah, 2010.

Direktorat Pembinaan Sekolah Luar Biasa, Pedoman Manajemen Dan Pembelajaran Sekolah Inklusi Tunanetra ,Jakarta: Direktorat Jendral Manajemen Pendidikan Dasar Dan Menengah, 2010.

Direktorat Pembinaan Sekolah Luar Biasa, Pedoman Manajemen Dan Pembelajaran Sekolah Inklusi Tunadaksa (D),Jakarta: Direktorat Jendral Manajemen Pendidikan Dasar Dan Menengah, 2010.

Direktorat Pembinaan Sekolah Luar Biasa, Pedoman Penyelenggaraan Pendidikan Terpadu/Inlkusi; Pengadaan dan pembinaan Tenaga Pendidikan, Jakarta: Direktorat Jendral Manajemen Pendidikan Dasar Dan Menengah, 2007.

Fathurrochman, I., Budiman, D. A., Alamsyahril, \& Kristiawan, M. (2019). Revitalization Management Of Islamic Boarding School Preventing The Radicalism. Restaurant Business, (10), 495-505. Retrieved from https://journals.eduindex.org/index.php/rb/article/view/9462

Fathurrochman, I. (2017). Implementasi Manajemen Kurikulum Dalam Upaya Meningkatkan Mutu Santri Pondok Pesantren Hidayatullah/Panti Asuhan Anak Soleh Curup [Implementation Of Curriculum Management An Effort To Improve The Quality Of Hidayatullah Islamic Boarding School]. Tadbir: Jurnal Studi Manajemen Pendidikan, 1(1), 85-104.

Fathurrochman, I. (2017). Pengembangan kompetensi pegawai aparatur sipil negara (ASN) Sekolah Tinggi Agama Islam Negeri (STAIN) Curup [The development of the competency of the state civil servant (ASN) STAIN Curup]. Manajer Pendidikan, 11(21), 120-129.

Ganiofam, Mengasub dan Mensukseskan Anak Berkebutuban Kbusus, Yogyakarta: Gara ilmu, 2010.

Hamalik, Oemar, Manajemen Pengembangan Kurikulum, Bandung: Kerja Sama UPI dan Remaja Rosdakarya, 2010.

Haris, Abdul, Pendidikan Anak Berkebutuban Khusu Autistik, Bandung: Alfabeta, 2006.

Hikmat, Manajemen Pendidikan, Bandung: Pustaka Setia, 2009.

Jupri, Hasan, et.al, "Model-Model Pengembangan Kurikulum" dalam AtTarbiyah Jurnal Pendidikan Islam, Vol.01, No.01, Januari-Juni 2010.

Moleong, Lexy J, Metode Penelitian Kualitayif, Bandung: Remaja Rosdakarya, 2010. Nuzuar, Fathurrochman, I., Amin, M., et al. (2017). Manajemen dan Metodologi Pendidikan Agama Islam. Curup; LP2 IAIN Curup. 
126 | TADBIR : Jurnal Studi Manajemen Pendidikan, Vol. 3, No. 2, November 2019

Ristianti, D. H., Danim, S., Winarto, H., \& Dharmayana, I. W. (2019). The Development Of Group Counselling Assessment Instruments. International Journal of Scientific \& Technology Research, 8(10), 267-272. Retrieved from http://www.ijstr.org/paper-references.php?ref=IJSTR1019-23814

Sagala, Syaiful, Kemempuan Profesional Guru dan Tenaga Kependidikan, Bandung: Alfabeta, 2009.

Sanjaya, Wina, Kurikulum dan Pembelajaran; Teori dan Praktik Pengembangan Kurikulum KTSP, Jakarta: Kencana, 2008.

Sanjaya, Wina, Perencanaan dan Desain Sistem Pembelajaran, Jakarta: Pranada Media Grup, 2009.

Sudjana, Nana, Pembinaan dan Pengembangan Kurikulum Di Sekolah, Bandung: Sinar Baru Algensindo, 2008.

Sukmadinata, Nana Syaodih, Pengembangan Kurikulum Teori dan Praktek, Bandung: Remaja Rosdakarya, 2002.

Sulistyorini. Manajemen Pendidikan Islam; Konsep Strategi dan Aplikasi, Yogyakarta: Teras, 2009.

Syamsudduha, Manajemen Pesantren Teori dan Praktek,Yogyakarta: Grhu Guru, 2004.

Undang-Undang, Sistem Pendidikan Nasional, Yogyakarta: Media Wacana Press, 2003. 
This page belongs to the TADBIR : Jurnal Studi Manajemen Pendidikan TADBIR : Jurnal Studi Manajemen Pendidikan vol. 3 , no. 2, November 2019 IAIN Curup - Bengkulu | p-ISSN 2580-3581; e-ISSN 2580-5037 